\title{
The Moderating Effect of Gender on The Influence of Religiosity on Frugal Behavior
}

\author{
D Asih ${ }^{1}$ \\ ${ }^{1}$ Universitas Mercu Buana, Jakarta; \\ 1.
}

\begin{abstract}
The purpose of the research is to analyze the causality relationship between gender-moderated religiosity and frugal behavior. This research is quantitative and data were collected by survey. The respondents of this study are students of Universitas Gadjah Mada and Universitas Mercu Buana, and the sample size was 292, consisting of 195 women and 97 men, using the purposive sampling methods. Data analysis was done using linear regression. The result of hyphothesis testing shows that influence of religiosity on frugal behavior was not significant. Classifying based on gender, there is found that the effect of religiosity of female on frugal behavior was significant. But on the male respondents, frugal behavior have not been significantly influenced by religiosity.
\end{abstract}

Keywords: Religiosity, Gender, and Frugal behavior.

\section{INTRODUCTION}

There is a shift from religious teachings related to being frugal and having selfrestrained toward a hedonistic one. Being rationally hedonistic is a common practice among the society members in which they emphasize on fulfilling their needs by consuming. Religious practices are related to consumption behavior. A religion is central to human experience as well as culture and is used as a way of lif.[1] stated that religion is contradictory to social science and cannot be well-defined. The definition depends on the context of the study. Methodological traps are still found in the studies related to religiousity, its measurement and research design [2]

In doing their daily activities, consumers defend their existance and realize their wishes. [3]. [4] proposed two concepts related to frugal shopping behavior. First, there are two main factors supporting frugal shopping behavior,i.e . external and internal ones. Some people practice frugality by limiting consumption, searching for values and cheap prices, and applying four Rs (reuse, repair, repurpose, and recycle) due to their financial limitations. They are not frugal but they are forced by external condition.Internal frugality is like a personal character who really wants to be frugal . [4] stated that frugality can be strengthened or weakened by the individual's cultural and social environments. Thus, frugality is a combination of external, social, cultural environments. 
Second, Goldsmith distinguished frugal behavior, on one hand, for eample ; preferring saving to consuming, going to a restaurant only when there is a discount,etc and frugal lifestyle encompassing acivities, interests, opinions, on the other hand. According to him, frugal lifestyle is boosted by psychological factors such as; values, personal characters, freedom. Not much research has been conducted to examine the constructs in explaining shopping behavior, especially frugal shopping behavior.

On one hand, religions can be used as the bases to build marketing strategies, on the other, religions teach the adherents to be frugal. According to [5], religion is a faith system, a practice over the response and understanding toward the sacred. It is a fundamental element in the society and it is related to many aspects of life and behavior. Religiosity affects the decision to buy products.

\subsection{Religiosity Conceptualization and Measurement}

[6] defined religiosity as religion's inner experience. According to et.al [7],religiosity is a concept encompassing individual's behaviors and the strength of their religious faith. [8] defined it as a willingnes to follow faith principles set by God. Religion is the motivation to have morality and to make it as the source of morality. [9] stated that religiosity is related to morality and it is an intepretation to ethical behavior. Based on the above definitions , [10] asserted that religiosity has three dimensions ; cognitive level ( faith, religious knowledge), affective level ( religious feeling) and motoric one ( going to house of worship and participating in the activities. Those dimensions are usually used to measure individual religiosity level. Religiosity is also defined as one's dependence on the teachings of one' religion which is reflected by the individual's behavior. Based on the available definitions, the researcher decided to use Barnett approach to conclude that a set of religious faiths (affective) are used to conclude one's religiosity level.

The dimensionality from this religious construct can be said to be an unsolvable problem, because religion is a human phenomenon that is diverse and complex, which covers fundamental things like behavior, attitude, values, beliefs, feelings, and experiences. Several researchers implicitly believe that religiosity is a unidimensional construct, meaning it is measured with a sole measurement. Meanwhile, a number of other researchers measure religiosity by using multidimensional measurements.

A multi-dimensional scale also needs to be developed to study this complicated religiosity construct. Table 1 below contains the dimensions from the religiosity construct of previous research:

TABEL 1. Religiosity Dimensions

\begin{tabular}{ccc}
\hline Author & Year & Dimension \\
\hline Allport \& Ross & 1967 & Religiosity intrinsic orientation \\
\hline & & Religiosity extrinsic orientation \\
\hline Stark \& Glock & 1968 & Religious conviction \\
\hline
\end{tabular}




\begin{tabular}{|c|c|c|}
\hline & & Religious knowledge \\
\hline & & Religious practice \\
\hline & & Religious experience \\
\hline & & Religious consequence \\
\hline \multirow[t]{3}{*}{$\begin{array}{l}\text { Wilkes, Burnett, \& } \\
\text { Howell }\end{array}$} & 1986 & Church attendance \\
\hline & & Importance of belief in religious values \\
\hline & & Self-preparedness of religiosity \\
\hline \multirow[t]{3}{*}{$\begin{array}{l}\text { Strayhorn, Weidman, \& } \\
\text { Larson }\end{array}$} & 1990 & Self-preparedness of religiosity \\
\hline & & Religious awareness \\
\hline & & Religious behavior \\
\hline \multirow[t]{2}{*}{ McDaniel \& Burnett } & 1990 & $\begin{array}{l}\text { Self-preparedness of religiosity, the } \\
\text { importance of religion }\end{array}$ \\
\hline & & $\begin{array}{l}\text { Church attendance, donation to religious } \\
\text { institution }\end{array}$ \\
\hline \multirow[t]{2}{*}{ Delener } & 1994 & Self-preparedness of religiosity \\
\hline & & Expression of religious affiliation \\
\hline \multirow[t]{4}{*}{ Sood \& Nasu } & 1995 & Self-preparedness of religiosity \\
\hline & & Belief in fundamental teachings \\
\hline & & $\begin{array}{c}\text { Importance of conviction in religious } \\
\text { values }\end{array}$ \\
\hline & & Religious behavior \\
\hline \multirow[t]{3}{*}{ France \& Kaldor } & 2002 & Belief in God \\
\hline & & The frequency of attending church \\
\hline & & Frequency of praying \\
\hline
\end{tabular}

Worthington, Wade,

Hight, McCullough, Berry,

Ripley, Berry, Schmitt,

Religiosity behavior

Bursley, \& O’Connor

\begin{tabular}{|c|c|c|}
\hline & & Motivational/ interpersonal religiosity \\
\hline \multirow[t]{5}{*}{ Khraim } & 2010 & Attitude towards Islamic financial services \\
\hline & & Attitude towards recent Islamic issues \\
\hline & & $\begin{array}{l}\text { Attitude towards sensitive products and } \\
\text { food consumption }\end{array}$ \\
\hline & & Religious education \\
\hline & & Islamic ethics \\
\hline Muhammad \& Mizerski & 2010 & Religious affiliation \\
\hline
\end{tabular}




\begin{tabular}{ll}
\hline & Religious knowledge \\
\hline Religious orientation \\
\hline Religious consequences \\
\hline Religious commitment \\
\hline
\end{tabular}

The measurement scale used in this research is Centrality Religiosity Scale/CRS). The scale refers to.multidimensional religiosity model proposed by [11]. It views religion from the sociological perspective. There are five core dimensions of religiosity that can be used as a framework for empirical studies. Glock's approach centers around religious institutions and social ecpectations. For example, the intellectual dimension must be in line with the fact that a religious person posesses much information and knowledge regarding his Holy Book. The experience dimension provides the knowledge that every religion has certain expectationsThe five core dimensions developed from sociological perspective also cover psychological ones. The intellectual and ideological dimension refer to the thought, personal practices, and general practices refer to experience, emotion, and perception. Thus, those dimensions can be considered as representing two perspectives namely ; sociological and psychological.[12]

In relation to construct validity, the centrality scale measurement has been empirically confirmed and it is highly correlated to one's religious identity. The correlation between CRS and self-evaluation regarding the importance of religion in one's life was 0,78 .

\subsection{The Conceptualization and Measurement of Frugal behavior}

Frugality has been part of our culture. Religions emphasize on the importance of harmonious life with the nature. Frugal life is a need to achieve peace and happiness. One of the oldest religions, Jainism has spread in India for a long time. Buddhist tradition also highlights the importance of being frugal. Three important teachings of Lao Tsu are : gentleness, frugality and humility. Those three will create a harmonious life between human and nature. The harmonious lfe will enable the energy to flow well; especially in the cases of wind and water.

The capitalist has a negative perception about being frugal.. In the enlightment era, religious perception on frugal behavior vanishes. It is always related to consumption. Louis de Jaucourt in [13] revived the old definition of frugality. Frugal behavior has two strengths namely it offers pleasure from being frugal and it enables us to follow religious teachings. Frugality opposes the consumption. Corruption is triggered by the consumptive behavior. Frugality will prevent corrupt behavior. Thus, it can be said that frugality can prevent corrupt behavior. A religious person will not commit corruption. Thus, it can be said that religiosity affects the shopping behavior of a person.

[14] found out that religiosity is negatively correlated to the the tendency to consume luxurious goods. It means religious people tend to be frugal in their shopping behavior. Thus, the following hyphotheses are proposed:

$\mathrm{H}_{1}$ : Religiosity has positively influenced to frugal behavior 
One of the antecedents of religiosity is gender. Some studies reveal that there are differences between religiosity in men and women . [15] stated that women have higher religiosity than men. [16] stated that relational schemes in men are diferent from those in women. For example: young girls tend to participate more than boys do in religious activities. Girls tend to think that faith is, and they are more committed to worship God and be involved religious groups. Thus, girls feel closer to .

[17] conducted a study about gender religiosity. The results show that religiosity in choosing investment is moderated by gender. Male Malay Muslims have different perspective about risk compared to the female ones. Based on the previous studies, the researcher proposes the following hypothesis

H2: The effects of religiosity on frugal behavior is moderated by gender

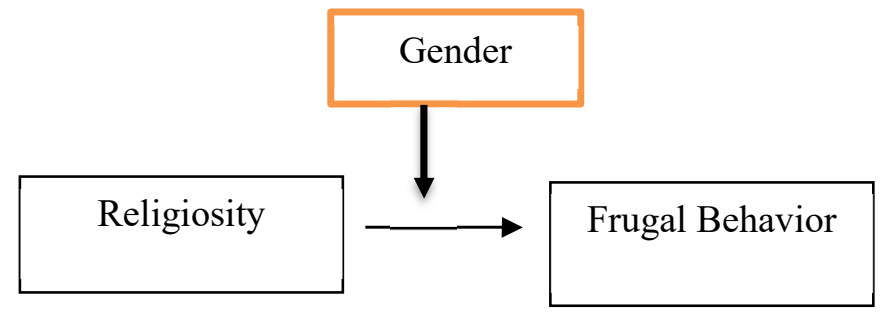

FIGURE 1. Conceptual Framework[3].

\section{RESEARCH METHOD}

The study is a quantitative one using causality design ; that is, to explain casuality relationships among independent and dependent variables. The primary data were gahered by survey, that is, by distibuting questionnaires among the students of Econmics and Bussines Faculty of Gadjah Mada University and Mercu Buana University, Jakarta.

The variables used were religiosity as the independent one and frugality as dependent one. The sampling technique used was non-probability sampling,namely covenience sampling.To analyze the data, simple linier regression analysis was used.

The reliability test was conducted to find out the reliability of the instrument by using Cronbach Alpha. The criteria used refer to [18], i.e. a variable is considered as reliable when the value of Cronbach Alpha is above 0,7. The validity test was conducted to investigate whether the instrument is able to reveal what is needed to be revealed. It was conducted by exploratory factor analysis. The data were tested by simple regression analysis. The hyphotheses were tested by the T-test. Besides, the causality relationship test was also conducted to differentiate gender-based samples.

\section{RESULTS AND DISCUSSION}


The Cronbach's Alpha value for religiosity was 0,922, and 0,919 for frugality. It means that the constructs were reliable. They are in accordance with the criteria [18] that requires The Cronbach's Alpha value 0,7 .

From the regression analysis, it was found that religiosity had no significant effect on frugality. The T-test showed the value of $-0,847$ and the probability was 0,398 . It was over 0,05 . Thus, the first hypothesis about the positive effect of religiosity on frugality was not supported.

Simple regression test was also applied to the samples basd on gender. The total samples were 292 students consisting of 195 female students and 97 male students. The result showed that religiosity had no significant effect on frugal behavior.

Separating the samples base on gender, For male samples, religiosity construct had no significant effect on frugal behavior. It means that frugal behavior for male cannot be explained by religiosity construct.

For female samples, the test showed that religiosity had significant effect on frugality. It is in accordance with the findings of [15] that showed religiosity was positively correlated to age and gender. It was found out that females were more religious than males The study of [15] emphasized on the effect of religiosity on life style. Thus, frugal behavior for males is not influenced by religiosity

The descriptive statistical analysis showed that the religiosity of females is higher than that of males. However, in relation to frugality, males are more frugal than females.

TABEL 2. Descriptive Statistics

\begin{tabular}{|c|c|c|c|c|}
\hline \multirow{2}{*}{ Construct } & \multicolumn{2}{|c|}{ Average } & \multicolumn{2}{|c|}{ Deviation Standar } \\
\hline & Male & Female & Male & Female \\
\hline Religiosity & 3,9462 & 4,1316 & 0,74594 & 0,63813 \\
\hline Frugal Behavior & 3,969 & 3,8299 & 1,23517 & 1,25443 \\
\hline
\end{tabular}

Sources: Data Analysis (2019)

\section{CONCLUSIONS}

The result showed that the first hypothesis was not supported meaning that there had no significant effect of religiosity on frugal behavior . By separating the gender, it was found out that religiosity had significant effect on frugality. Thus, the second hypothesis was supported, i.e., the effect of religiosity on frugal behavior is moderated by gender

There are many limitations of this study, e.g . the use of students as respondents made the age variation and other demographic factors limited. [15] revealed that besides gender, religiosity antecedent is age. The older a person becomes, the more religious that person . The age maturity affects a person's religiosity. Thus, it is suggested the future studies use wider respondents so that the analysis can be more comprehensive. 


\section{REFERENCES}

[1] A. . Eister, "A Sociology of Religion by Michael Hill Review by : Allan W . Eister Book reviews," vol. 25, no. 1, pp. 115-116, 2014.

[2] D. Berry, "Methodological pitfalls in the study of religiosity and spirituality," West. J. Nurs. Res., vol. 27, no. 5, pp. 628-647, 2005.

[3] J. L. Lastovicka, L. A. Bettencourt, R. S. Hughner, and R. J. Kuntze, "Lifestyle of the Tight and Frugal: Theory and Measurement," J. Consum. Res., vol. 26, no. 1, pp. 8598, 1999.

[4] R. E. Goldsmith and L. R. Flynn, "The Etiology of Frugal Spending: A Partial Replication and Extension," Compr. Psychol., vol. 4, p. 09.20.CP.4.4, 2015.

[5] R. Johnstone, B; Wallace, R.A; \& Ronald, "Religion and Society in Interaction," Contemp. Sociol., vol. 5, no. 4, p. 1976, 1976.

[6] G. W. Allport and J. M. Ross, "Personal religious orientation and prejudice," J. Pers. Soc. Psychol., vol. 5, no. 4, pp. 432-443, 1967.

[7] M. Cornwall and S. L. Albrecht, "The Dimensions of Religiosity: A Conceptual Model with an Empirical Test Author ( s ): Marie Cornwall, Stan L . Albrecht, Perry H . Cunningham and Brian L . Pitcher Published by : Religious Research Association, Inc . Stable URL : http://www.jstor.org,” Rev. Relig. Res., vol. 27, no. 3, pp. 226-244, 2017.

[8] S. W. McDaniel and J. J. Burnett, "Consumer religiosity and retail store evaluative criteria," J. Acad. Mark. Sci., vol. 18, no. 2, pp. 101-112, 1990.

[9] G. Magill, "Theology in business ethics: Appealing to the religious imagination," J. Bus. Ethics, vol. 11, no. 2, pp. 129-135, 1992.

[10] T. Barnett, K. Bass, and G. Brown, "Religiosity, ethical ideology, and intentions to report a peer's wrongdoing," J. Bus. Ethics, vol. 15, no. 11, pp. 1161-1174, 1996.

[11] J. D. . Davidson, "Glock' s Model of Religious Commitment: Assessing Some Different Approaches and Results," Comp. Longitud. Stud., vol. 16, no. 2, pp. 83-93, 2018.

[12] S. Huber and O. W. Huber, "The Centrality of Religiosity Scale (CRS)," Religions, vol. 3, no. 3, pp. 710-724, 2012.

[13] D. A.-R. Roiland Damien, "Frugality, A Positive Principle to Promote Sustainable Development," J. Agric. Environ. Ethics, vol. v. 29, no. 4, pp. 571-585-2016 v.29 no.4, 2016.

[14] G. Tjahjono, "Religiosity and the Intention to Buy Luxury Goods Among Young Indonesian Muslims in Jakarta Godo Tjahjono,” p. 199, 2014.

[15] R. E. Wilkes, J. J. Burnett, and R. D. Howell, "On the meaning and measurement of religiosity in consumer research,” J. Acad. Mark. Sci., vol. 14, no. 1, pp. 47-56, 1986.

[16] P. Gökhan, Ö. Asst, P. Volkan, Ö. Asst, and P. Meral, "Concurrent Validity of Different Religiosity Scales Used in Researches of Marketing Ethics and A Proposal For A New Religiosity Scale Pazarlama Etiği Araştırmalarında Kullanılan Farklı Dindarlık Ölçeklerinin Eş Zamanlı Geçerliliği ve Yeni Bir Dindarlık Öl,” pp. 15-28.

[17] M. S. Rahman, "Young consumer's perception on foreign made fast moving consumer goods: The role of religiosity, spirituality and animosity," Int. J. Bus. Manag. Sci., vol. 5, no. 2, pp. 103-118, 2012.

[18] I. R. Nunnally, J.C. and Bernstein, "Psychometric Theory," McGraw-Hill, New York, 1994. 